\title{
HUBUNGAN DANA BOK DAN MOTIVASI DENGAN KINERJA PETUGAS KIA
}

\author{
Raisha Octavariny, ${ }^{1}$ Sermi Iyana Swita Sinaga ${ }^{2}$ \\ Institut Kesehatan Medistra Lubuk Pakam \\ Jl. Sudirman No.38 Lubuk Pakam Kec. Lubuk Pakam Kab.Deli Serdang \\ Email: raisha.oct@gmail.com
}

\begin{abstract}
Purpose BOK is to review assist local government to implement health care Appropriate Minimum Service Standards (MSS) Health to review Accelerate the achievement of the MDGs WITH improve costs kos health center, village health post (Poskedes) and Integrated Service Post (Posyandu) hearts organizing health services, To run the program needs a strong motivation For KIA officer. Number wherewith Research husband is WITH THE observational cross-sectional design carried out in October 2015. A sample of 48 Namely orangutan KIA officer working in the region Pematangsiantar City Health Department. Data collection using a questionnaire distributed To the respondents. Data analysis was conducted WITH THE chi-square test significance level of 95\%. Results of the analysis we found the majority of officers KIA motivation and low performance that is $50 \%$ and $52.1 \%$, $p$ value $=0.035$, which means there is a connection with the performance of funds BOK $K I A$ officer and $p$ value $=0.002$ which means that there is a relationship of motivation with performance KIA BOK paid-up funds and Motivation MAY affect the boarding costs so that the KIA Officer Program has been drafted Posted community health centers can run properly Subscription with sufficient funds and Motivation Officer Yang High so that there can be KIA issue is resolved.
\end{abstract}

Keywords: BOK funds, Motivation, Working Performance KIA officer

\section{PENDAhUluAN}

Dari data Dinas Kesehatan Kota Pematangsiantar pada tahun 2014 didapat cakupan PWS-KIA antara lain cakupan pemeriksaan kehamilan yang pertama (K1) sebesar 94,2\% (target 100\%), cakupan pemeriksaan kehamilan yang ke empat kali (K4) sebesar 84,8\% (target 95\%), cakupan persalinan oleh tenaga kesehatan sebesar $92,6 \%$ (target $95 \%$ ), cakupan penanganan komplikasi kebidanan sebesar 75,2\% (target $80 \%$ ) dan cakupan pelayanan nifas sebesar $88,3 \%$ (target $95 \%$ ). Jika dilihat pencapaian tersebut cukup tinggi namun belum memenuhi target yang telah ditetapkan.

Jumlah dana yang terbatas terkadang tidak dapat memenuhi kebutuhan puskesmas untuk menjalankan program yang telah disusun, petugas kesehatan tidak bisa melaksanakan pelayanan secara optimal dikarenakan dana yang tidak memadai, kondisi ini secara tidak langsung berhubungan dengan tindakan dalam memberikan pelayanan kesehatan ke masyarakat sehingga program tidak berjalan dengan baik.

Berdasarkan latar belakang diatas maka peneliti tertarik untuk melakukan penelitian tentang hubungan dana BOK dan motivasi dengan kinerja petugas KIA di wilayah kerja Dinas Kesehatan Kota Pematangsiantar Tahun 2015.

Tujuan penelitian ini adalah untuk mengetahui hubungan dana BOK dan motivasi dengan kinerja petugas KIA di wilayah kerja Dinas Kesehatan Kota Pematangsiantar.

Rumusan masalah penelitian ini adalah apakah dana BOK dan motivasi memiliki hubungan dengan kinerja petugas KIA di 
wilayah kerja Dinas Kesehatan Kota Pematangsiantar Tahun 2015.

\section{METODE PENELITIAN}

Penelitian ini berupa penelitian observasional dengan jenis cross-sactional. Penelitian ini dilaksanakan pada bulan Oktober 2015 di wilayah kerja Dinas Kesehatan Kota Pematangsiantar

\section{HASIL}

Dari Hasil Penelitian di dapat bahwa:

Tabel 1

Hubungan Dana BOK dengan Kinerja Petugas KIA

\begin{tabular}{lccccccc}
\hline Dana & \multicolumn{4}{c}{ Kinerja } & Jumlah & $\begin{array}{c}\boldsymbol{p} \\
\text { BOK }\end{array}$ \\
\cline { 2 - 6 } & \multicolumn{2}{c}{ Rendah } & \multicolumn{2}{c}{ Tinggi } & & & $\begin{array}{c}\text { val } \\
\end{array}$ \\
\cline { 2 - 7 } & $\mathbf{n}$ & $\%$ & $\mathbf{n}$ & $\%$ & $\mathbf{n}$ & $\%$ & ue \\
\hline Cukup & 3 & 4,4 & 0 & 95, & 3 & 10 & \\
& & & & 6 & & 0 & 0,03 \\
Tidak & 22 & 48, & 23 & 51, & 45 & 10 & 5 \\
Cukup & & 9 & & 1 & & 0 & \\
\hline
\end{tabular}

Tabel 2

Hubungan Motivasi dengan Kinerja Petugas KIA

\begin{tabular}{|c|c|c|c|c|c|c|c|}
\hline \multirow{3}{*}{$\begin{array}{l}\text { Moti } \\
\text { vasi }\end{array}$} & \multicolumn{4}{|c|}{ Kinerja } & \multirow{2}{*}{\multicolumn{2}{|c|}{ Jumlah }} & \multirow{3}{*}{ 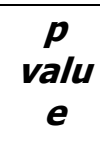 } \\
\hline & \multicolumn{2}{|c|}{ Rendah } & \multicolumn{2}{|c|}{ Tinggi } & & & \\
\hline & $\mathbf{n}$ & $\%$ & $\mathbf{n}$ & $\%$ & $\mathbf{n}$ & $\%$ & \\
\hline $\begin{array}{l}\text { Rend } \\
\text { ah }\end{array}$ & 20 & $\begin{array}{c}74, \\
1\end{array}$ & 7 & $\begin{array}{c}25, \\
9\end{array}$ & 27 & $\begin{array}{c}10 \\
0 \\
0\end{array}$ & 0,002 \\
\hline Tinggi & 5 & $\begin{array}{c}23 \\
8\end{array}$ & 16 & $\begin{array}{c}76, \\
2\end{array}$ & 21 & $\begin{array}{c}10 \\
0, \\
0\end{array}$ & \\
\hline
\end{tabular}

Tabel 3

Hubungan Motivasi Instrinsik dengan Kinerja Petugas KIA

\begin{tabular}{|c|c|c|c|c|c|c|c|}
\hline \multirow{3}{*}{$\begin{array}{c}\text { Moti } \\
\text { vasi } \\
\text { Inst } \\
\text { rinsi } \\
\mathbf{k}\end{array}$} & \multicolumn{4}{|c|}{ Kinerja } & \multirow{2}{*}{\multicolumn{2}{|c|}{ Jumlah }} & \multirow{3}{*}{$\begin{array}{l}p \\
\text { va }\end{array}$} \\
\hline & \multicolumn{2}{|c|}{ Rendah } & \multicolumn{2}{|c|}{ Tinggi } & & & \\
\hline & $n$ & $\%$ & $\mathbf{n}$ & $\%$ & $\mathbf{n}$ & $\%$ & \\
\hline & 16 & $\begin{array}{c}66, \\
7\end{array}$ & 8 & $\begin{array}{c}33 \\
3\end{array}$ & 24 & $\begin{array}{c}100, \\
0\end{array}$ & \\
\hline $\begin{array}{l}\text { Ting } \\
\text { gi }\end{array}$ & $\gamma$ & $\begin{array}{c}37, \\
5\end{array}$ & 15 & 62 & 2. & 100, & \\
\hline
\end{tabular}

Tabel 4

Hubungan Motivasi Ekstrinsik dengan Kinerja Petugas KIA

\begin{tabular}{|c|c|c|c|c|c|c|c|}
\hline \multirow{3}{*}{$\begin{array}{c}\text { Motiv } \\
\text { asi } \\
\text { ekstri } \\
\text { nsik }\end{array}$} & \multicolumn{4}{|c|}{ Kinerja } & \multirow{2}{*}{\multicolumn{2}{|c|}{ Jumlah }} & \multirow{3}{*}{$\begin{array}{c}p \\
\text { val } \\
\text { ue }\end{array}$} \\
\hline & \multicolumn{2}{|c|}{ Rendah } & \multicolumn{2}{|c|}{ Tinggi } & & & \\
\hline & $\mathbf{n}$ & $\%$ & $\mathbf{n}$ & $\%$ & $\mathbf{n}$ & $\%$ & \\
\hline $\begin{array}{l}\text { Renda } \\
\mathrm{h}\end{array}$ & 21 & $\begin{array}{c}65, \\
6\end{array}$ & $\begin{array}{l}1 \\
1\end{array}$ & $\begin{array}{c}34, \\
4\end{array}$ & 32 & $\begin{array}{c}100 \\
0\end{array}$ & 0,0 \\
\hline Tin & 4 & $\begin{array}{c}25, \\
0\end{array}$ & $\begin{array}{l}1 \\
2\end{array}$ & $\begin{array}{c}75, \\
0\end{array}$ & 16 & $\begin{array}{c}100 \\
0\end{array}$ & 19 \\
\hline
\end{tabular}

\section{Pembahasan}

\section{Dana Bantuan Operasional Kesehatan (BOK)}

Dana BOK yang disalurkan ke puskesmas mayoritas cukup yaitu sebanyak 45 orang $(93,8 \%)$. Dari 45 orang petugas KIA $(93,8 \%)$ menyatakan dana BOK yang diberikan mencukupi untuk menjalankan program KIA di puskesmas, hal ini dapat dilihat dari pencapaian program yg telah direncankan disetiap tahunnya. Adapun bagi puskesmas yang dana BOK nya tidak mencukupi dikarenakan program yang telah disusun tidak sesuai dengan masalah kesehatan yang sedang dihadapi sehingga masalah tidak terselesaikan atau penyebab lainnya adalah dikarenakan dana BOK yang dialokasikan untuk program KIA tidak sesuai dengan kebutuhan.

Pada dasarnya puskesmas merencanakan program sesuai dengan masalah yang ada di masyarakat kemudian mengajukan ke dinas kesehatan sehingga dana BOK yang dialokasikan sesuai dengan kebutuhan, namun pada kenyataannya puskesmas membuat perencanaan program setelah dana dialokasikan sehingga terkadang pendistribusian dana BOK di beberapa elemen tidak mencukupi.

\section{Motivasi Kerja Petugas KIA}

Dapat dilihat bahwa petugas KIA yang memiliki motivasi instrinsik tinggi dan rendah adalah sama besar yaitu 24 orang $(50 \%)$, hal ini dikarenakan petugas KIA merasa bahwa 
adalah sudah menjadi tanggung jawab untuk menyusun dan melaksanakan program KIA yang telah ditetapkan serta memanfaatkan dana yang ada.

Untuk meningkatkan motivasi ekstrinsik perlu adanya dukungan dari teman sejawat dan atasan, keadaan kantor yang aman dan nyaman, kerjasama yang bagus antar petugas, reward misalnya pengajuan menjadi pegawai teladan atau pengajuan kenaikan jabatan yang diberikan oleh atasan secara tidak langsung memberikan motivasi kepada petugas KIA. Petugas KIA juga tidak menerima gaji tambahan, namun memperoleh uang transport yang dialokasikan dari dana BOK.

\section{Kinerja Petugas KIA}

Sekaitan tentang kinerja petugas KIA dapat dilihat bahwa mayoritas petugas KIA memiliki kinerja yang tinggi dalam melaksanakan tugas sebagai petugas KIA di masing-masing puskesmas yaitu sebayak 44 orang $(91,7 \%)$.

\section{Hubungan Dana BOK dengan Kinerja Petugas KIA}

Berdasarkan hasil uji statistik tentang hubungan dana BOK dengan kinerja petugas KIA di dapat bahwa nilai $p$ value $=0,035<$ 0,05 , yang berarti ada hubungan antara dana BOK dengan kinerja petugas KIA.

Tersedianya dana BOK di puskesmas sebenarnya sangat membantu petugas dalam menjalankan program promotif dan preventif yang mana sebelumnya dana operasional puskesmas sangat terbatas. Jangkauan pelayanan bisa lebih luas karena adanya dana operasional yang mendukung program puskesmas. Dana yang cukup untuk membiayai program KIA akan mampu meningkatkan kinerja petugas KIA. Hasil penelitian Hani di Kabupaten Gowa menyatakan bahwa dana BOK terbukti dapat meningkatkan kinerja puskesmas.

Dari hasil penelitian juga didapat bahwa ketersediaan dana BOK yang tidak cukup memiliki resiko 2,01 kali lebih besar memiliki kinerja yang rendah karena secara tidak langsung ketersediaan dana yang cukup dapat memotivasi petugas untuk melaksanakan pelayanan dengan lebih baik dengan memanfaatkan dana untuk melengkapi sarana dan prasarana yang diperlukan sehingga meminimalisir kendala yang dapat menghambat pemberian pelayanan kesehatan. Dengan dana yang cukup diharapkan dapat mengoptimalkan dan meningkatkan kinerja petugas KIA.

\section{Hubungan Motivasi dengan Kinerja Petugas KIA}

Berdasarkan hasil uji statistik tentang hubungan motivasi dengan kinerja petugas KIA di dapat bahwa $p$ value $=0,002$, yang berarti ada hubungan antara motivasi kerja dengan kinerja petugas KIA. Terdapat juga hubungan antara motivasi instrinsik dan ekstrinsik terhadap kinerja yang dihasilkan yaitu masing-masing memiliki $p$ value $=0,043$ dan 0,019.

Dapat disimpulkan bahwa ada hubungan yang erat antara motivasi kerja baik instrinsik maupun ekstrinsik yang diperoleh oleh petugas KIA dengan kinerja yang dihasilkan dalam melaksanakan tugas sebagai petugas KIA. Dari hasil penelitian dapat dilihat bahwa motivasi yang rendah dapat menimbulkan kinerja yang rendah.

Untuk dapat meningkatkan kinerja petugas KIA diperlukan peningkatan motivasi melalui pemberian penghargaan baik berupa finansial maupun non finansial dan mengalokasikan dana bantuan operasional kesehatan, memberikan pelatihan teknis secara berkelanjutan terutama tentang pembuatan dan pemanfaatan PWS.

\section{KESIMPULAN}

a. Ada hubungan dana BOK yang dialokasikan dengan kinerja petugas KIA dalam melaksanakan program yang telah ditetapkan

b. Ada hubungan motivasi kerja dengan kinerja petugas KIA dalam melaksanakan program yang telah ditetapkan

c. Ada hubungan dana BOK dan motivasi dengan kinerja petugas KIA dalam 
melaksanakan program yang telah ditetapkan

\section{DAFTAR PUSTAKA}

Beratha, Oka dkk. 2013. Hubungan Karakteristik, motivasi, dan dana BOK dengan kinerja petugas KIA puskesmas di Kabupaten Gianyar.

Bertha H. 2013. Hubungan Ketersediaan dana (BOK)dengan kinerja petugas KIA puskesmas di Kabupaten Gianyar

Dinas Kesehatan Kota Pematangsiantar, Laporan Cakupan PWS-KIA Tahun 2014

Handoko HT. 2001. Manajemen Sumber Daya Manusia. Edisi 2. Yogyakarta: BPFE

Hani SU. 2012. Pengaruh Pemberian Dana Bantuan Operasional Kesehatan (BOK) terhadap Kinerja Puskesmas Bontonompo II Kabupaten Gowa [Skripsi] .Makasar: Universitas Patria Artha

Hani L, 2012. Pengaruh Pemberian Dana Bantuan Operasional Kesehatan (BOK) terhadap Kinerja Puskesmas Bontonompo II Kabupaten Gowa

Kemenkes RI, 2008, Peraturan Menteri Kesehatan RI Nomor 741/MENKES/PER/VII/2008

Tentang Standar Pelayanan Minimal, Kementerian Kesehatan Republik Indonesia, Jakarta 2010. Rencana Strategi Kementrian Kesehatan, Kementrian Kesehatan Republik Indonesia, Jakarta

2011. Petunjuk Teknis bantuan Operasional Kesehatan, Kementerian Kesehatan Republik Indonesia, Jakarta

Lutiarsi D. 2011. Faktor-faktor yang mempengaruhi motivasi kerja di Kabupaten Semarang.

Pani ME, 2012. Trisnantoro L dan Zaenab SN, Evaluasi Implementasi Kebijakan Bantuan Operasional Kesehatan
Di Tiga Puskesmas Kabupaten Ende Provinsi Nusa Tenggara Timur Tahun 2011, Jurnal Kebijakan Kesehatan Indonesia

Pratiwi NL, 2013. Policy Review: Kajian Kebijakan Penyaluran Dana Bantuan Operasional Kesehatan Dalam Pencapaian Kesehatan Ibu Dan Anak (MDGs 1,4,5) Di Jawa Timur Indonesia, Pusat Humaniora Kebijakan Kesehatan dan Pemberdayaan Masyarakat, Surabaya

Purwanti E, Ayubi D. 2007. Hubungan antara Kepemimpinan Kepala Puskesmas dan Karakteristik Petugas Gizi Puskesmas di Kabupaten Kerawang [Tesis]. Jakarta: FKM UI

Samsualam, Indar, Syafar M. Analisis 2008. Hubungan Karakteristik Individu dan Motivasi dengan Kinerja Asuhan Perawatan di BP Rumah Sakit Umum Labuang Baji Makasar. Jurnal Kesehatan Masyarakat Madani: 01(2).

Siagian. 2008. Masa Kerja, http://pdfmachine.com, a great PDF writer utility/ di akses pada tanggal 13 november 2012.

Tanjung D \& Supardan. 2011. Pengelolaan Pendapatan dan Anggaran Daerah. Pengelolaan Pendapatan dan Anggaran Daerah Penerbit Graha Ilmu, Yogyakarta

Handoko T.H. 2009.Manajemen, Penerbit BPFE Edisi Kedua, Yogyakarta

WHO. 2012. Maternal Mortality. diakses pada tanggal 16 Juli 2015. http://www.who.int/mediacentre/fa ctsheets/fs348/en/ 